\title{
Analgesic, anti-inflammatory and NF-KB inhibitory activity of aerial parts of Cestrum diurnum
}

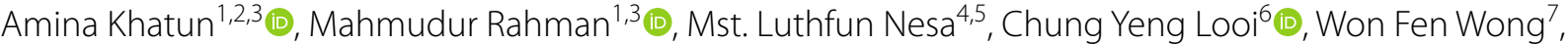 \\ Hazrina Hazni ${ }^{8,9}$, Mohamad Azrul bin Mahdzir ${ }^{8}$, Shaikh Jamal Uddin ${ }^{3}$ (D, Khalijah Awang 8,9 (1) and \\ Jamil A. Shilpi ${ }^{3^{*}}$ (1)
}

\begin{abstract}
Background: Cestrum diurnum L. (Solanaceae), locally known as buno-Hasnahena, is widely used in different traditional medicinal practices to treat pain, burn, swelling and related disorders. Adequate evidence is not available to support its medicinal properties for further use and drug development. Present study was designed to evaluate its traditional use in pain and inflammation with further characterisation of its chemical constituents through liquid chromatography-mass spectroscopic (LC-MS) analysis.
\end{abstract}

Methods: Antinociceptive and analgesic potential of methanol extract of the aerial parts of $C$. diurnum was carried out using carrageenan induced paw oedema and formalin induced paw licking test in mice at the oral doses of 150 and $300 \mathrm{mg} / \mathrm{kg}$ body weight. Inhibition of the inflammatory mediator nuclear factor kappa B (NF-KB) was evaluated by tumour necrosis factor a (TNF-a) induced NF-KB activation assay in macrophage cells at the concentration of $100 \mathrm{\mu g} / \mathrm{ml}$. LC-MS analysis of the extract was performed to characterise the active component responsible for bioactivities.

Results: The extract significantly inhibited $(p<0.05)$ carrageenan induced paw oedema at both doses tested and the effect persisted throughout the entire experimental period of $3 \mathrm{~h}$ with the highest activity ( $50 \%$ inhibition) observed at 3rd $h$. Further, the extract significantly inhibited $(p<0.05)$ formalin induced paw licking both in the early and late phase at the aforementioned dose levels. The extract also downregulated the expression of NF-kB p65 protein in the TNF-a induced NF-KB activation assay. LC-MS analysis of the extract indicated the presence of some important secondary metabolites including nicotine, nornicotine, ursolic acid, vitamin $\mathrm{D}_{3}$ and its derivatives.

Conclusions: The results of this study supported the folkloric uses of the plant in pain and inflammations. The insights and observations suggest the action might involve downregulation of NF-KB p65 protein expression and/or inhibition of autacoids (histamine, serotonin, prostaglandin).

Keywords: Carrageenan induced paw oedema, Formalin induced paw licking, NF-kB downregulation, LC-MS

\footnotetext{
*Correspondence: jamilshilpi@yahoo.com; jamilshilpi@pharm.ku.ac.bd

${ }^{3}$ Pharmacy Discipline, Life Science School, Khulna University,

Khulna 9208, Bangladesh

Full list of author information is available at the end of the article
}

\section{Introduction}

Cestrum diurnum L., (Family: Solanaceae), the dayblooming jasmine, day jasmine, day-blooming cestrum, wild jasmine, Chinese inkberry, locally known as Buno-Hasnahena in Bengali is an erect evergreen woody shrub with numerous leafy branches and simple leaves [1-7]. The plant yields sweet smelling white 
flowers in short clusters and black fruits which are nearly globular shaped berries. The plant is originated from West Indies and eventually dispersed throughout the world and became naturalized throughout the tropical and subtropical regions of India and Bangladesh.

Due to the content of similar bioactive phytoconstituents, many Cestrum species are used in Ayurveda, traditional Chinese medicine, South and North American folklore medicines for the treatment of burn and swelling [1-9]. The leaf paste of $C$. diurnum is used by Malayali tribe of Tamil Nadu to treat joint pain [10]. The plant demonstrated to possess a wide range of pharmacological activities including antioxidant [4], anticancer [4], hypolipidemic [11], antipsoriatic [12], thrombolytic [13], antidiabetic [5], larvicidal [6] and antimicrobial [14] properties. Previous phytochemical analysis of the crude extracts revealed the presence of phytochemicals including alkaloids $[14,15]$, norlignans, glycosides [9], saponin glycosides $[8,16]$, triterpenes (ursolic acid, $\beta$-amyrin) and steroids ( $\beta$-sitosterol, vitamin $\left.\mathrm{D}_{3}, 1,25-(\mathrm{OH})_{2} \mathrm{D}_{3}\right)[8$, $17,18]$. Leaves of $C$. diurnum was found to be rich in $\beta$-carotene, lutein, xanthine, calcium, vitamin $D_{3}[19]$, calcitriol- a naturally occurring active form of vitamin $\mathrm{D}_{3}[12]$ and the calcinogenic glycoside-1,25-dihydroxycholocalciferol which leads to vitamin D toxicity [6]. C. diurnum also contains different fatty acids including myristic, palmitic, stearic, oleic and linoleic acid [18]. Previous studies found that C. diurnum can effectively prevent and ameliorate bone metabolic disorders by enhancing calcium and phosphate uptake [20, 21]. The plant is also used in vitamin D deficiency and widely used as a component of cosmetic preparations for the prevention or treatment of skin disorders with wrinkled, flaky, aged, photo-damaged skin caused by the lack of vitamin D [22].

C. diurnum has been well documented in medicinal plant repositories and herbal compendia, and used as herbal raw material for the management of pain and inflammatory disorders in complementary and alternative medicine throughout the globe. The plant extract was found to be safe and well tolerated in several clinical trials $[2,7,12]$. Nevertheless, adequate evidence is not available to support its therapeutic value in the treatment of pain and inflammation with underlying mechanism. Subsequently, present study was designed to investigate the aerial part of $C$. diurnum for analgesic, anti-inflammatory activities, to provide scientific evidence for its use as a conventional folk medicine, determine its role on the inflammatory mediator nuclear factor kappa $B(N F-\kappa B)$ and characterise its secondary metabolites with medicinal importance.

\section{Materials and methods \\ Collection and identification of plant material}

Aerial parts of the plant Cestrum diurnum L. (Family: Solanaceae) was collected from Dumuria area of Khulna district, Bangladesh (Coordinate $22.8083^{\circ} \mathrm{N}, 89.4250^{\circ}$ E). The plant specimen was identified by the experts at Bangladesh National Herbarium (voucher specimen no. DACB 38792) [23].

\section{Test animals}

Young Swiss albino mice of either sex, 3-4 weeks old, weighing $20-25 \mathrm{~g}$ were purchased from the Animal Resources Branch of the International Centre for Diarrhoeal Diseases and Research, Bangladesh (ICDDR,B) [24]. The animals were kept in the animal house of Manarat International University under standard laboratory conditions (relative humidity 55-65\%, room temperature $25.0 \pm 2.0^{\circ} \mathrm{C}$ and $12 \mathrm{~h}$ light-dark cycle) for adaptation [23]. They were fed with ICDDR,B formulated pelleted standard diet and water ad libitum.

\section{Extract preparation}

Shed dried plant material was ground into a coarse powder and stored in an airtight container until extraction commenced [24]. Powered plant material (135g) was macerated in $400 \mathrm{ml}$ of methanol (Merck, Germany) for 3days with occasional sonication. The filtrate was evaporated to dryness using a rotary vacuum evaporator to get the crude extract (yield $7.4 \%$ of the dry powder).

\section{Carrageenan-induced paw oedema test}

Anti-inflammatory activity was tested by carrageenan induced paw oedema model in mice [25]. In brief, $0.1 \mathrm{ml}$ of $1 \% \mathrm{w} / \mathrm{v}$ carrageenan suspended in $1 \%$ carboxymethylcellulose was injected into the sub-plantar tissue of the left hind paw of each mouse as the chemical inducer of chronic inflammation. Mice were divided into four groups containing six animals in each. Test groups received plant extract at the doses of 150 and $300 \mathrm{mg} / \mathrm{kg}$ body weight, while control and positive control group received vehicle and diclofenac sodium $(10 \mathrm{mg} / \mathrm{kg}$ body weight), respectively. The paw thickness was measured using a calliper at $0,60,120$ and $180 \mathrm{~min}$ after the carrageenan injection. Inhibition of oedema was calculated using the following formula where $T_{t}$ and $T_{0}$ are the thickness of paw oedema in test/positive control and control group, respectively.

(\%) Inhibition $=\left(T_{0}-\frac{T_{t}}{T_{0}}\right) \times 100$ 


\section{Formalin induced paw licking test}

A formalin-induced nociception model was employed to evaluate the central analgesic activity of the extract $[24,26,27]$. Mice were grouped in control, test and positive control receiving vehicle, extract (150 and $300 \mathrm{mg} /$ $\mathrm{kg}$ body weight, per oral) and diclofenac sodium $(10 \mathrm{mg} /$ $\mathrm{kg}$ body weight, intraperitoneally), respectively. Formalin solution $(0.2 \mathrm{ml}$ of freshly prepared $5 \% \mathrm{v} / \mathrm{v}$ formalin in distilled water) was injected into the dorsal surface of the right hind paw $30 \mathrm{~min}$ after the treatments. The mice were observed for the time spent for apparent spontaneous pain behaviours, i.e., licking of the injected hind paw during the early phase $(0-5 \mathrm{~min})$ and late phase (15-30 min) of formalin injection. The biting, flinching, shaking, and favouring of the injected paw were also monitored [26, 27].

\section{TNF- $a$ induced NF-KB activation assay}

To elucidate the possible role of $C$. diurnum extract on the inflammatory mechanism, a NF- $\mathrm{kB}$ translocation activity was performed using NF- $\mathrm{kB}$ activation kit (ThermoFisher Scientific, Waltham, MA) [28]. For this purpose, RAW 264.7 macrophage cells (Sigma-Aldrich) were seeded in 96-well plate overnight and then treated with (a) C. diurnum extract alone at $12.5 \mu \mathrm{M}$ or (b) $10 \mathrm{ng} / \mathrm{ml}$ TNF- $\alpha$ alone or (c) $12.5 \mu \mathrm{M}$ of $C$. diurnum extract and $10 \mathrm{ng} / \mathrm{ml}$ TNF- $\alpha$ in combination. Then $4 \%$ formaldehyde was used to fix the cells for $15 \mathrm{~min}$ followed by the addition of $0.1 \%$ Triton X-100 in phosphate buffer saline (PBS) to make the cells permeable. The cell were then incubated with NF-kB primary rabbit antibody to detect the endogenous levels of total NF- $\mathrm{kB}$ protein to determine the involvement of the NF- $\mathrm{kB}$ protein in the priming of autoimmune $T$ cell responses $[28,29]$. The cells were then treated with goat anti-mouse secondary antibody (IgG) conjugated with staining solution DyLightTM 649 for $1 \mathrm{~h}$. The cells were then rinsed in triplicate with wash buffer II (1 X PBS with $1 \%$ Tween-20). The nuclei were stained with Hoechst 33258 to visualized them. Finally, the plate with stained cells were imaged using Cellomics ArrayScan HCS reader (ThermoFisher Scientific, Waltham, MA). Data were captured, extracted and analysed with ArrayScan II Data Acquisition and Data Viewer version 3.0 (Cellomics).

\section{Liquid chromatography-mass spectrometry (LC-MS) analysis}

LC-MS analysis of the extract was performed to characterise phytochemical content with possible link to the obeserved bioactivities [24]. High-resolution electrospray ionisation (HR-ESI) mass spectra were recorded on 6530 Accurate-Mass Q-TOF LC/MS spectrometer
(Agilent Technologies) equipped with ZORBAX Eclipse XDB-C18 Rapid Resolution column (HT $4.6 \mathrm{~mm}$ i.d. $\times 50 \mathrm{~mm} \times 1.8 \mu \mathrm{m})$. The extract was injected at a volume of $10 \mu \mathrm{l}(1 \mathrm{mg} / \mathrm{ml})$ with a flow rate of $1 \mathrm{ml} / \mathrm{min}$. A gradient elution with solvent $\mathrm{A}$ ( $1 \%$ trifluroacetic acid in water) and $\mathrm{B}(\mathrm{MeOH})$ starting at $95 \% \mathrm{~A} 5 \% \mathrm{~B}$ to reach $100 \% \mathrm{~B}$ in 40 min was adopted. Other parameters include capillary voltage of $3500 \mathrm{~V}$, nebuliser pressure $35 \mathrm{psi}$, drying gas flow $8 \mathrm{~L} / \mathrm{min}$, drying gas temperature $200^{\circ} \mathrm{C}$. The mass was recorded in the range of $\mathrm{m} / \mathrm{z} 100-1000$ and expressed as total ion chromatogram (TIC).

\section{Data analysis}

Values from animal model analyses are expressed as mean $\pm S E M$ of six replicates. Results were analysed using Microsoft Excel. Statistical analyses were done using one-way ANOVA followed by Dunnett's test. Statistical differences between control and test groups were calculated by Student's $t$-test and were considered as statistically significant at $p<0.05$.

\section{Results}

\section{Results of carrageenan-induced paw oedema}

The carrageenan-induced paw oedema used in this study is a well-accepted model to evaluate natural products against acute inflammation [30]. C. diurnum extract prevented carrageenan-induced paw oedema throughout the entire experimental period of $3 \mathrm{~h}$ at the doses of 150 and $300 \mathrm{mg} / \mathrm{kg}$. The experiment also demonstrated that the result observed for test extract at the dose of $300 \mathrm{mg} /$ $\mathrm{kg}$ was comparable to that of diclofenac sodium, used as positive control in this study (Table 1).

\section{Results of formalin induced paw licking}

C. diurnum extract, at the doses of 150 and $300 \mathrm{mg} / \mathrm{kg}$, significantly $(p<0.05)$ suppressed the licking activity both in the early and late phase of formalin-induced pain in mice as compared to the control (Table 2). The observed effect was stronger at the higher dose $(300 \mathrm{mg} / \mathrm{kg})$ of the extract tested.

\section{Effect on TNF- $a$ induced NF-KB activation}

In the absence of TNF- $\alpha$, NF- $\mathrm{kB}$ p 65 remains in the cytoplasm of RAW 264.7 macrophage cells. In response to the stimulation by TNF $\alpha, N F-\kappa B$ p 65 protein translocates from cytoplasm into the nucleus implying NF- $\mathrm{kB}$ activation. $C$. diurnum extract did not inhibit TNF- $\alpha-$-mediated nuclear translocation of NF-kB p65 very strongly at $100 \mu \mathrm{g} / \mathrm{ml}$ although the result was significantly different from that of control (Fig. 1). Interestingly, the total NF-kB $p 65$ protein expression was found downregulated, 
Table 1 Effect of $C$. diurnum extract on carrageenan induced paw oedema in mice

\begin{tabular}{|c|c|c|c|c|}
\hline \multirow[t]{2}{*}{ Treatment } & \multirow{2}{*}{$\begin{array}{l}\text { Dose ( } \mathrm{mg} / \mathrm{kg} \text { body } \\
\text { weight) }\end{array}$} & \multicolumn{3}{|c|}{ Paw oedema in $\mathrm{mm}$ (\% inhibition) } \\
\hline & & $1 \mathrm{st} \mathrm{h}$ & 2nd h & $3 r d h$ \\
\hline Control & - & $4.67 \pm 0.33$ & $3.67 \pm 0.33$ & $2.33 \pm 0.21$ \\
\hline \multirow[t]{2}{*}{ C. diurnum extract } & 150 & $3.83 \pm 0.17^{*}(18 \%)$ & $2.67 \pm 0.21 *(27 \%)$ & $1.67 \pm 0.21^{*}(29 \%)$ \\
\hline & 300 & $3.50 \pm 0.34^{*}(25 \%)$ & $2.50 \pm 0.18^{*}(32 \%)$ & $1.17 \pm 0.11^{*}(50 \%)$ \\
\hline Diclofenac sodium & 10 & $4.00 \pm 0.13(14 \%)$ & $2.3 \pm 0.21^{*}(36 \%)$ & $1.75 \pm 0.25(25 \%)$ \\
\hline
\end{tabular}

Values are expressed as mean \pm SEM; $n=6 ;{ }^{*} p<0.05$

Table 2 Effect of $C$. diurnum extract on formalin induced paw licking in mice

\begin{tabular}{llll}
\hline Treatment & Dose $\mathbf{( m g / k g}$ body weight) & \multicolumn{2}{l}{ Number of licking response (\% Inhibition) } \\
\cline { 3 - 4 } & & Early phase (0-5 min) & Late phase (15-30 min) \\
\hline Control & - & $8.50 \pm 0.76$ & $23.00 \pm 1.32$ \\
C. diurnum extract & 150 & $7.67 \pm 1.21^{*}(10 \%)$ & $15.00 \pm 1.00^{*}(35 \%)$ \\
& 300 & $7.50 \pm 0.35^{*}(12 \%)$ & $11.33 \pm 1.21^{*}(51 \%)$ \\
Diclofenac sodium & 10 & $5.33 \pm 0.49^{*}(37 \%)$ & $8.00 \pm 1.67^{*}(65 \%)$ \\
\hline
\end{tabular}

Values are expressed as mean $\pm \mathrm{SEM} ; n=6$; ${ }^{*} p<0.05$

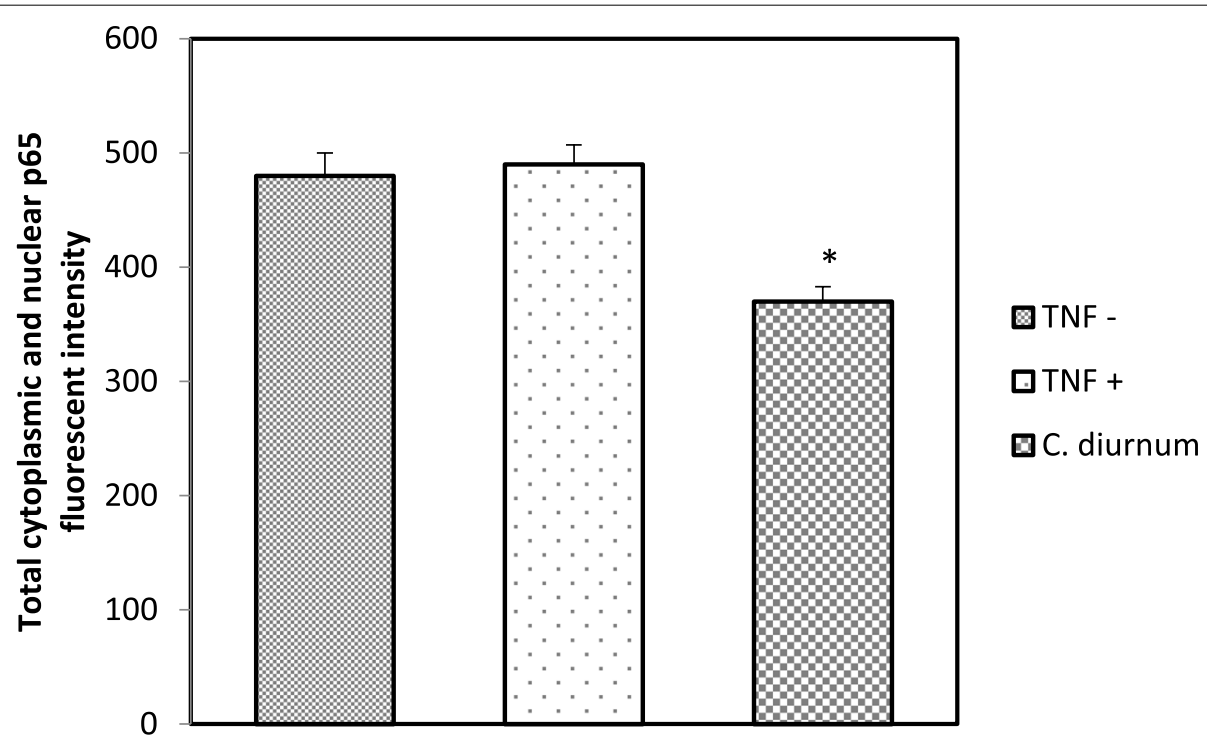

Fig. 1 C. diurnum extract induced inhibition of tumour necrosis factor a (TNFa)-induced nuclear translocation of inflammatory mediator nuclear factor kappa B (NF-KB) in RAW 264.7 cells $\left({ }^{*} p<0.05\right)$

indicating the extract exerts its anti-inflammatory effect through the inhibition of NF-kB p65 protein expression (Fig. 2).

\section{Results of LC-MS analysis}

LC-MS analysis of $C$. diurnum revealed the presence of some pharmacologically important secondary metabolites already reported earlier from this species, which include vitamin $\mathrm{D}_{3}$ and its derivatives (Table 3). Total ion chromatogram and MS spectrum for the major peaks is provided in the supplementary file.

\section{Discussion}

Inflammation and the search for its cure has been the centre of attention for last few decades due to its involvement to many diseases including arthritis, cancer, 


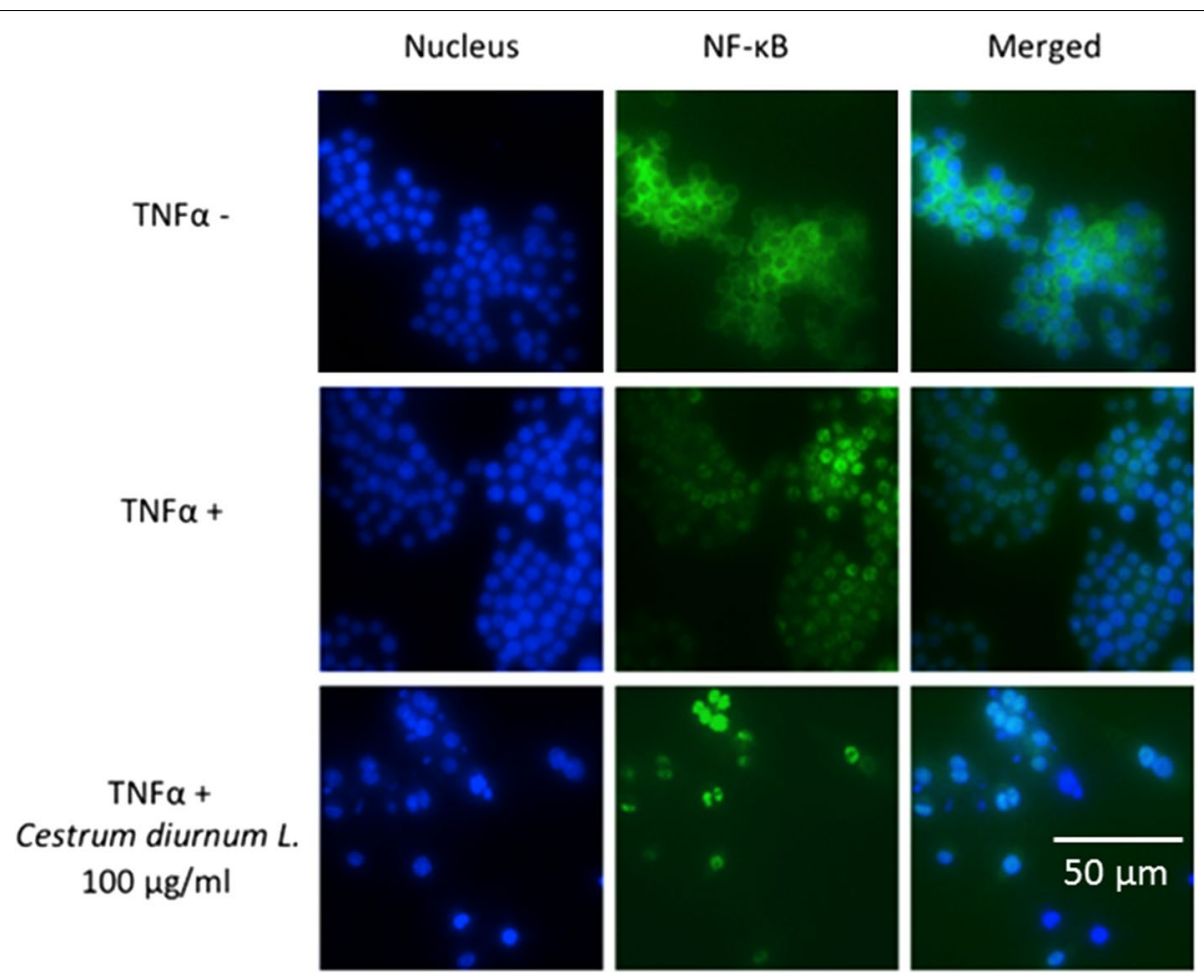

Fig. 2 TNFa induced nuclear translocation of NF-KB in RAW 264.7 cells. Cells were pre-treated with $100 \mu \mathrm{g} / \mathrm{ml}$ of C. diurnum extract prior to stimulation with $1 \mu \mathrm{g} / \mathrm{ml}$ of TNFa for $30 \mathrm{~min}$. Cells were fixed, stained for NF-KB and visualized using HSC

Table 3 Detection of compounds previously reported from C. diurnum

\begin{tabular}{llllllll}
\hline Name & Molecular formula & Class & $\mathbf{M}+\mathbf{H}$ & $\mathbf{M}+\mathbf{N a}$ & Exact mass & $\mathbf{t}_{\mathbf{r}}$ & Reference \\
\hline Medusaside $\mathrm{B}$ & $\mathrm{C}_{26} \mathrm{H}_{34} \mathrm{O}_{12}$ & Lignan & 539.2319 & - & 538.2050 & 17.54 & {$[1]$} \\
Liriodendrin & $\mathrm{C}_{36} \mathrm{H}_{50} \mathrm{O}_{18}$ & Lignan & - & 793.3956 & 742.2684 & 24.72 & {$[1]$} \\
Cholecalciferol & $\mathrm{C}_{27} \mathrm{H}_{44} \mathrm{O}$ & Steroid & 385.2925 & - & 384.3392 & 32.26 & {$[6]$} \\
Calcifediol & $\mathrm{C}_{27} \mathrm{H}_{44} \mathrm{O}_{2}$ & Steroid & 401.2182 & - & 400.3341 & 24.97 & {$[6]$} \\
Calcitriol & $\mathrm{C}_{27} \mathrm{H}_{44} \mathrm{O}_{3}$ & Steroid & 417.1596 & 439.3579 & 416.3290 & 21.58 & {$[6]$} \\
Nicotine & $\mathrm{C}_{10} \mathrm{H}_{14} \mathrm{~N}_{2}$ & Alkaloid & - & 185.1173 & 162.1157 & 23.28 & {$[6]$} \\
Nornicotine & $\mathrm{C}_{9} \mathrm{H}_{12} \mathrm{~N}_{2}$ & Alkaloid & 149.0224 & 171.1018 & 148.1000 & 29.44 & {$[6]$} \\
Tigogenin & $\mathrm{C}_{27} \mathrm{H}_{44} \mathrm{O}_{3}$ & Saponin & 417.1569 & 439.3579 & 416.3290 & 21.58 & {$[9]$} \\
Ursolic acid & $\mathrm{C}_{30} \mathrm{H}_{48} \mathrm{O}_{3}$ & Triterpene & 457.2570 & 479.3513 & 456.3603 & 32.69 & {$[9]$} \\
\hline
\end{tabular}

diabetes, obesity and neurodegeneration. Although inflammatory response is a vital defensive mechanism of human body, chronic inflammation can lead to various pathological conditions such as chronic infection and autoimmune diseases [31, 32]. Inflammatory process is a complex cascade of events that encompass cellular response with subsequent release of inflammatory molecules (e.g. COX-2, 5-LOX and TNF- $\alpha$ ) regulated by pro-inflammatory transcription factors (e.g. NF- $\mathrm{kB}$ and STAT3), and activation of other cells (e.g. leucocytes and platelets) [33]. Inhibition of NF- $\mathrm{kB}$ is considered as one of the most important targets to control inflammation since this regulatory protein serves as the key checkpoint for inflammatory responses [34, 35]. Some natural products including curcumin, emodin, capsaicin and resveratrol have been found to inhibit NF- $\mathrm{kB}$. However, lack of bioavailability and other issued hindered their way to become therapeutic agents [36].

Natural products still serve as one of the major sources for new drug discovery for the treatment of pain, inflammation and related disorders. Plants used in the treatment of inflammatory disorders in ethnobotanical 
practices may hold the promise to be investigated for novel anti-inflammatory agents [3-7]. In this study, $C$. diurnum, a well-documented medicinal plant used in the traditional and complementary health care systems for the treatment of joint pain and swelling. Carrageenan induced paw oedema and formalin induced paw licking, two most widely accepted animal models to screen anti-inflammatory activity of crude extracts or pure compounds, were used for the investigation of analgesic and anti-inflammatory activity of the methanol extract of $C$. diurnum aerial parts [25, 30-32]. In addition, the extract was further tested in RAW 264.7 cells for its possible role on NF-kB protein [28]. Methanol was chosen for maceration of plant material due to its ability to extract a wide range of secondary metabolites of both polar and nonpolar nature with the added advantage of the ease of its removal.

In the carrageenan-induced acute inflammation test, the total duration of carrageenan-induced paw oedema in mice model is represented by a biphasic model. The first phase of inflammation is triggered by histamine and serotonin released after carrageenan injection and lasts for about two and a half hours [37]. The second phase of inflammation is due to the prostaglandin synthesis which starts after the first phase and can last up to $6 \mathrm{~h}$ $[25,38]$. In this study, both the test extract and diclofenac sodium produced mild inhibition of paw oedema in the early phase of inflammation, however the inhibition was more noticeable during the late phase indicating their key inhibitory role on cyclooxygenase mediated prostaglandin synthesis.

Again, the biphasic model of formalin-induced nociception can be categorized into neurogenic $(0-5 \mathrm{~min})$ and inflammatory pain $(15-30 \mathrm{~min})$, respectively. The early phase of neurogenic pain is due to the chemical stimulation of the nociceptors predominantly $\mathrm{C}$-fibres, while the late phase of tonic pain is a combination of peripheral inflammatory responses and functional changes in spinal cord level [39]. Drugs that act primarily on the central nervous system such as narcotic analgesics inhibit both phases while steroids and NSAIDs suppress mainly the late phase [40]. In this study, the extract suppressed the gradual increase of paw licking in both phases which implies that it may contain constituents that act both centrally and peripherally. On top of this, formalin-induced nociception model is also recognized as one of the most suitable evaluation test procedures against chronic inflammation, as it closely resembles human arthritis [41]. Thus, both the approaches carried out in this study successfully support the use of this plant in ethnobotanical practice for alleviating pain and inflammatory conditions and explaining its utility in arthritic pain.

To understand the underlying mechanism of antiinflammatory effect, RAW 264.7 cells were treated with the extract before stimulating them with TNF- $\alpha$, a potent inducer and activator of NF- $\mathrm{KB}$. The NF- $\mathrm{KB}$ protein family is a central mediator of inflammatory responses and plays a crucial role in the development of acute or chronic inflammation [28, 42]. It consists of five subfamilies that share same DNA binding domain and dimerisation domain. The NF-kB proteins are associated with each other to form homo- or heterodimeric complexes, which remain inactive in the cytoplasm by sequestering with inhibitory proteins (IKB). Upon stimulation by various factors including lipopolysaccharides (LPS) or TNF- $\alpha$, I $\mathrm{B}$ is degraded and dissociated from NF- $\kappa B$. As a result, NF- $\mathrm{KB}$ migrates from the cytoplasm into the nucleus and triggers the transcription of numerous genes involved in pro-inflammatory responses $[43,44]$.

Chemical inducer of pain like low doses of acetic acid, formalin and carrageenan causes the activation of peritoneal macrophages and mast cells, the cellular sites of cyclooxygenase enzyme activity during acute peritoneal inflammation, that leads to the local release of cytokines such as TNF- $\alpha$ and interleukin $1 \beta$ as well as other pain mediators [45]. In this study, effect of the $C$. diurnum aerial extract was compared to the effect induced by chemical inducers and the extract was found to inhibit tumor necrosis factor $\alpha$ (TNF- $\alpha$ ) induced NF- $k B$ activation.

Various classes of natural products have been identified with the capability to downregulate NF- $\mathrm{kB}$, prevent nuclear translocation of NF- $\mathrm{kB}$ and/or inhibit their DNA binding $[46,47]$. The results in this study indicate that C. diurnum extract can downregulate the expression of NF-kB p65 protein. Literatures on NF- $\mathrm{kB}$ inhibitory natural products reveal that most of the identified compounds prevent nuclear translocation of NF- $\mathrm{KB}$ while very few of them such as catechin and epigallocatechin gallate act through the downregulation of NF- $\mathrm{kB}$ expression $[48,49]$. Therefore, the extract may be an important source of NF-KB inhibitor that acts through its downregulation.

LC-MS analysis of the crude extract revealed the presence of a number of bioactive compounds including ursolic acid, nicotine and nornicotine. Ursolic acid, a ubiquitous plant pentacyclic triterpene, was found in a previous study to inhibit prostaglandin biosynthesis through the inhibition of COX-2 enzyme [50]. However, another study showed that the anti-inflammatory effect of ursolic acid involves to the inhibition of NF- $\mathrm{KB}$ activation and its DNA binding [51]. Thus, the 
downregulation of NF- $\mathrm{kB}$ by $C$. diurnum extract might be due to compound(s) other than ursolic acid. Nicotine and nornicotine cannot be ruled out as well since they were reported for anti-inflammatory [52] and analgesic [53] activity, respectively. To elucidate the molecular mechanisms of the bioactive components, the bioactivity of individual components could be analysed using in vivo cell-specific approaches or in silico assays [54-56]. Concurrent occurrence and bioavailability of two or more components may synergies or antagonise the medicinal activity of each other. As the extract possessed multiple components together, combined effect of the components could be observed for any agonism or antagonism [57].

Inflammation is a physiological response to injury, microbial attack or malignancy [58]. Pain is just one of the manifestations of the inflammatory responses and prolonged inflammation can aggravate an already existing disease as well as new disease progression including cancer [59]. Present study suggests that the plant C. diurnum can be useful in the treatment of pain, inflammation and diseases that involves NF- $\mathrm{KB}$ mediated inflammatory response.

\section{Conclusion}

This preliminary study with $C$. diurnum is a part of the continuing endeavour to identify medicinal plants that find their use in pain and inflammation in traditional medicine [60-63]. Results of the current investigation underpinned the traditional use of $C$. diurnum in inflammatory pain. In parallel, the insight of this study implies that the plant may not be suitable for long-term use due to the chance of over exposure to vitamin $D_{3}$ and its derivatives, however proved itself interesting enough for bioassay guided study to find new natural anti-inflammatory agent. Inhibition of prostaglandin synthesis and downregulation of NF-kB p65 protein synthesis could be the underlying mechanisms for the observed activity. This is the first report of antinociceptive, anti-inflammatory and NF-kB inhibitory activity of the plant $C$. diurnum which provides validation to currently unavailable evidences of its traditional uses as well as opens the door to develop new drug molecule against pain and related disorders.

\footnotetext{
Abbreviations

NF-kB: Nuclear factor kappa B; ICDDR,B: International Centre for Diarrhoeal Diseases and Research, Bangladesh; TNF-a: Tumor necrosis factor alpha; RAW 264.7 cells: Murine macrophage cell line; RPMI: Roswell Park Memorial Institute Medium; LC-MS: Liquid chromatography mass spectrometry; HR-ESI: High resolution electrospray ionisation; QTOF: Quadropole time-of-flight; SEM: Standard error of mean; ANOVA: Analysis of variance; NSAID: Nonsteroidal anti-inflammatory drug; IKB: Inhibitor of KB proteins; COX-2: Clycooxygenase enzyme-2.
}

\section{Supplementary Information}

The online version contains supplementary material available at https://doi. org/10.1186/s40816-022-00340-5.

Additional file 1: Figure S1. Total ion chromatogram (TIC) of C. diurnum extract. Figure S2. MS spectrum of C. diurnum extract at $24.72 \mathrm{~min}$. Figure S3. MS spectrum of $C$. diurnum extract at $32.26 \mathrm{~min}$. Figure $\mathrm{S4}$. MS spectrum of $C$. diurnum extract at 24.97 min. Figure S5. MS spectrum of $C$. diurnum extract at $21.58 \mathrm{~min}$. Figure $\mathbf{S 6}$. MS spectrum of $C$. diurnum extract at $23.28 \mathrm{~min}$. Figure S7. MS spectrum of C. diurnum extract at $29.44 \mathrm{~min}$. Figure S8. MS spectrum of $C$. diurnum extract at $21.58 \mathrm{~min}$. Figure S9. MS spectrum of $C$. diurnum extract at $32.69 \mathrm{~min}$.

\section{Acknowledgements}

Not applicable.

\section{Authors' contributions}

AK and MR designed the study, MLN, WFW and HH did the in vivo, in vitro assay, and LC-MS analysis, respectively. KA, AK, MR, CYL, MAM, SJU, JAS assisted in the preparation of the manuscript. The author(s) read and approved the final manuscript.

Funding

No.

Availability of data and materials

Datasets used in the study are available from the corresponding author on request.

\section{Declarations}

\section{Ethics approval and consent to participate}

The research was carried out according to the standard guidelines for research with animals and the experimental protocol approved by the Animal Ethics Committee, Manarat International University (Reference no: MIU/ AHEC/01/2013).

\section{Consent for publication}

Not applicable.

\section{Competing interests}

The authors declare no conflict of interest.

\section{Author details}

${ }^{1}$ Southern Cross Plant Science, Southern Cross University, Lismore, NSW 2480, Australia. ${ }^{2}$ Department of Pharmacy, Manarat International University, Dhaka 1216, Bangladesh. ${ }^{3}$ Pharmacy Discipline, Life Science School, Khulna University, Khulna 9208, Bangladesh. ${ }^{4}$ Department of Pharmacy, State University of Bangladesh, Dhaka 1205, Bangladesh. ${ }^{5}$ Department of Pharmacy, Atish Dipankar University of Science and Technology, Dhaka 1213, Bangladesh. ${ }^{6}$ School of Biosciences, Faculty of Health and Medical Sciences, Taylor's University, 5, 47500 Subang Jaya, Malaysia. ${ }^{7}$ Department of Medical Microbiology, Faculty of Medicine, University of Malaya, 50603 Kuala Lumpur, Malaysia. ${ }^{8}$ Department of Chemistry, University of Malaya, 50603 Kuala Lumpur, Malaysia. ${ }^{9}$ Centre for Natural Products and Drug Discovery, University of Malaya, 50603 Kuala Lumpur, Malaysia.

Received: 30 September 2020 Accepted: 16 January 2022

Published online: 07 March 2022

\section{References}

1. Karawya MS, Rizk AM, Hammouda FM, Diab AM, Ahmed ZF. Phytochemical investigation of certain Cestrum species. Plant Med. 1971;20(06):363-7.

2. Shadab H, Khan MN, Haq FU, Ali H, El-Seedi HR, Musharraf SG. Crossmixing study of a poisonous Cestrum species, Cestrum diurnum in herbal 
raw material by chemical fingerprinting using LC-ESI-QTOF-MS/MS. Arab J Chem. 2020;13(11):7851-9.

3. Shaista A, Amrita P. Delicate, fragrant, lady of the night-a medicinal gift. J Med Plant Stud. 2016;4(6):13-7.

4. Manzoor A, Qaisar U, Parveen Z, Siddique S, Sardar AA, Ishaq N. In vitro anticancer and antioxidant potential of Cestrum species. Pak J Pharm Sci. 2020;33:1535-41.

5. Jalal M, Shaheen S, Saddiqe Z, Harun N, Abbas M, Khan F. Scanning electron microscopic screening; can it be a taxonomic tool for identification of traditional therapeutic plants. Microsc Res Tech. 2021;84(4):730-45.

6. Ghosh A, Chandra G. Biocontrol efficacy of Cestrum diurnum L.(Solanaceae: Solanales) against the larval forms of Anopheles stephensi. Nat Prod Res. 2006:20(04):371-9.

7. Ghosh A, Chowdhury N, Chandra G. Laboratory evaluation of a phytosteroid compound of mature leaves of Day Jasmine (Solanaceae: Solanales) against larvae of Culex quinquefasciatus (Diptera: Culicidae) and nontarget organisms. Parasit Res. 2008;103(2):271-7.

8. Fouad MA, Mohamed KM, Kamel MS, Matsunami K, Otsuka H. Cesdiurins I-III, steroidal saponins from Cestrum diurnum L. J Nat Med. 2008:62:168-73.

9. Mohamed KM, Fouad MA, Matsunami K, Kamel MS, Otsuka H. A new norlignan glycoside from Cestrum diurnum L. Arkivoc. 2007;13:63-70.

10. Vaidyanathan D, Sisubalan N, Ghouse Basha M. Survey of ethnomedicinal plants and folklore studies on malayali tribals of vellakadai village a part of shervaroy range in eastern ghats, Tamil nadu. Int J Recent Sci Res. 2014;5:1368-80.

11. Ghosh A, Bhattacharjee I, Chandra G. Hypolipidemic effect of steroid compound from Cestrum diurnum (Solanaceae: Solanales) in normocholesterolemic albino rat. Nat Prod Res. 2019;33:573-6.

12. Bandi LP, Acharya S, Hegde V. Clinical efficacy of Dinamallika (Cestrum diurnum) in kitibha kustha (poriasis). Ayurpharm Int J Ayur Alli Sci. 2018;7:101-8.

13. Khatun A, Chowdhury U, Jahan A, Rahman M. Cytotoxic and thrombolytic activity of the aerial part of Cestrum diurnum L. (Solanaceae). PharmacolOnline. 2014;1:109-13.

14. Halim AF, Collins RP, Berigari MS. Alkaloids produced by Cestrum nocturnum and Cestrum diurnum. Planta Med. 1971;20:44-53.

15. Prema TP, Raghuramulu N. Free vitamin $D_{3}$ metabolites in Cestrum diurnum leaves. Phytochemistry. 1994;37:677-81.

16. Begum A, Patnaik A, Basha S, Raghavendra G, Pandey S, Sarma B. Effect of leaf extracts and steroidal saponin of Cestrum diurnum $L$. on spore germination and mycelial growth of some fungi. EJEAFChe. 2011;10:3097-103.

17. Chakravarti RN, Datta S, Mitra MN. Tigogenin and ursolic acid from Cestrum diurnum Linn. Experientia. 1964;20:200.

18. Karawya MS, Rizk AM, Hammouda FM, Diab AM, Ahmed ZF. Phytochemical investigation of certain Cestrum species. General analysis, lipids and triterpenoids. Planta Med. 1971;20:363-7.

19. Chennaiah S, Bhaskarachary K, Rao SB, Raghuramulu N. Nutritional and chemical evaluation of Cestrum diurnum leaves. Indian J Nutr Diet. 2009:46:101-5.

20. Mello J, Habermehl G. Effects of calcinogenic plants--qualitative and quantitative evaluation. Dtsch Tierarztl Wochenschr. 1998;105:25-9.

21. Peterlik M, Wasserman RH. Stimulatory effect of 1,25-dihydroxycholecalciferol-like substances from Solanum malacoxylon and Cestrum diurnum on phosphate transport in chick jejunum. J Nutr. 1978;108:1673-9.

22. Pillai S, Gottlieb KA, Brinker AM, Mahajan M, Rawlings AV. Cosmetic compositions containing phytovitamin D. US Patent US5776461 A, $26071997 ; 1997$.

23. Rahman M, Khatun A, Rashid HA, Sufian M, Salam FB, Khan M, et al. Methods for bio-evaluation of traditional medicines. J Ayurvedic Trad Med. 2014;2(1):25.

24. Khatun A, Rahman M, Rahman M, Hossain H, Jahan IA, Nesa M. Antioxidant, antinociceptive and CNS activities of Viscum orientale and high sensitive quantification of bioactive polyphenols by UPLC. Front Pharmacol. 2016:29(7):176.

25. Morris CJ. Carrageenan-induced paw edema in the rat and mouse. In: Winyard PG, Willoughby DA, editors. Inflammation protocols. Methods in molecular biology, vol. 225. Totowa: Humana Press Inc; 2003. p. 115-21.

26. Rahman M, Khatun A, Nesa ML, Hossain H, Jahan IA. Bioactive polyphenols from the methanol extract of Cnicus arvensis (L.) Roth demonstrated antinociceptive and central nervous system depressant activities in mice. Evid Based Complement Alternat Med. 2015;2015:794729.

27. Rahman SMM, Atikullah M, Islam MN, Mohaimenul M, Ahammad F, Islam MS, et al. Anti-inflammatory, antinociceptive and antidiarrhoeal activities of methanol and ethyl acetate extract of Hemigraphis alternata leaves in mice. Clin Phytosci. 2019;5:16.

28. Leong KH, Looi CY, Loong XM, Cheah FK, Supratman U, Litaudon M, et al. Cycloart-24-ene-26-ol-3-one, a new cycloartane isolated from leaves of Aglaia exima triggers tumour necrosis factor-receptor 1-mediated caspase-dependent apoptosis in colon cancer cell line. PLoS One. 2016;11(4):e0152652.

29. Mamula MJ, Lin RH, Janeway CA, Hardin JA. Breaking T cell tolerance with foreign and self co-immunogens. A study of autoimmune $B$ and $T$ cell epitopes of cytochrome c. J Immunol. 1992;149(3):789-95.

30. Mansouri MT, Hemmati AA, Naghizadeh B, Mard SA, Rezaie A, Ghorbanzadeh B. A study of the mechanisms underlying the anti-inflammatory effect of ellagic acid in carrageenan-induced paw edema in rats. Ind $J$ Pharmacol. 2015:47(3):292.

31. Medzhitov R. Origin and physiological roles of inflammation. Nature. 2008:454:428-35.

32. Arulselvan P, Fard MT, Tan WS, Gothai S, Fakurazi S, Norhaizan ME, et al. Role of antioxidants and natural products in inflammation. Oxidative Med Cell Longev. 2016;2016:5276130.

33. Nathan C. Points of control in inflammation. Nature. 2002;420:846-52.

34. Mitchell S, Vargas J, Hoffmann A. Signaling via the NFKB system. WIREs Syst Biol Med. 2016;8:227-41.

35. Pabon NA, Zhang Q, Cruz JA, Schipper DL, Camacho CJ, Lee REC. A network-centric approach to drugging TNF-induced NF-KB signaling. Nat Commun. 2019;10:860.

36. Gupta SC, Kunnumakkara AB, Aggarwal S, Aggarwal BB. Inflammation, a double-edge sword for cancer and other age-related diseases. Front Immunol. 2018;9:2160.

37. Hovanet MV, Ancuceanu RV, Dinu M, Oprea E, Budura EA, Negres S, et al. Toxicity and anti-inflammatory activity of Ziziphus jujuba Mill. leaves. Farmacia. 2016;64:802-8.

38. Levy L. Carrageenan paw edema in the mouse. Life Sci. 1969;8:601-6.

39. Tjolsen A, Berge OG, Hunskaar S, Rosland JH, Hole K. The formalin test: an evaluation of the method. Pain. 1992;51:5-17.

40. Elisabetsky E, Amador TA, Albuquerque RR, Nunes DS, Carvalho ADCT. Analgesic activity of Psychotria colorata (Willd. ex R. \& S.) Muell. Arg. alkaloids. J Ethnopharmacol. 1995;48:77-83.

41. Greenwald RA. Animal models for evaluation of arthritis drugs. Methods Find Exp Clin Pharmacol. 1991;13:75-83.

42. Shawish HB, Wong WY, Wong YL, Loh SW, Looi CY, Hassandarvish P, et al. Nickel(II) complex of polyhydroxybenzaldehyde N4-thiosemicarbazone exhibits anti-inflammatory activity by inhibiting NF-kappaB transactivation. PLoS One. 2014;9:e100933.

43. Tak PP, Firestein GS. NF-kappaB: a key role in inflammatory diseases. J Clin Invest. 2001;107:7-11.

44. Napetschnig J, Wu H. Molecular basis of NF-kappaB signaling. Annu Rev Biophys. 2013:42:443-68.

45. Afridi R, Khan AU, Khalid S, Shal B, Rasheed H, Ullah MZ, et al. Anti-hyperalgesic properties of a flavanone derivative Poncirin in acute and chronic inflammatory pain models in mice. BMC Pharmacol Toxicol. 2019;20(1):1-6.

46. Nam NH. Naturally occurring NF-kappaB inhibitors. Mini Rev Med Chem. 2006;6:945-51.

47. Golan-Goldhirsh A, Gopas J. Plant derived inhibitors of NF-kB. Phytochem Rev. 2014;13:107-21.

48. Bharrhan S, Koul A, Chopra K, Rishi P. Catechin suppresses an array of signalling molecules and modulates alcohol-induced endotoxin mediated liver injury in a rat model. PLoS One. 2011;6:e20635.

49. Giakoustidis AE, Giakoustidis DE, Koliakou K, Kaldrymidou E, lliadis S, Antoniadis $\mathrm{N}$, et al. Inhibition of intestinal ischemia/repurfusion induced apoptosis and necrosis via down-regulation of the NF-kB, c-Jun and caspace-3 expression by epigallocatechin-3-gallate administration. Free Radic Res. 2008:42:180-8.

50. Ringbom T, Segura L, Noreen Y, Perera P, Bohlin L. Ursolic acid from Plantago major, a selective inhibitor of cyclooxygenase-2 catalyzed prostaglandin biosynthesis. J Nat Prod. 1998;61:1212-5.

51. Shishodia S, Majumdar S, Banerjee S, Aggarwal BB. Ursolic acid inhibits nuclear factor-kappaB activation induced by carcinogenic agents 
through suppression of IkappaBalpha kinase and p65 phosphorylation: correlation with down-regulation of cyclooxygenase 2, matrix metalloproteinase 9, and cyclin D1. Cancer Res. 2003;63:4375-83.

52. Kalra R, Singh SP, Pena-Philippides JC, Langley RJ, Razani-Boroujerdi S, Sopori ML. Immunosuppressive and anti-inflammatory effects of nicotine administered by patch in an animal model. Clin Diagn Lab Immunol. 2004;11:563-8.

53. Holtman JR, Crooks PA, Dwoskin L, Wala EP. Nornicotine for the treatment of pain. US patent WO2008063556 A2, 16112007; 2007.

54. Qiao Q, Chen L, Li X, Lu X, Xu Q. Roles of dietary bioactive peptides in redox balance and metabolic disorders. Oxid Med Cel Long. 2021;15:2021.

55. Iwata M, Sawada R, Iwata H, Kotera M, Yamanishi Y. Elucidating the modes of action for bioactive compounds in a cell-specific manner by largescale chemically-induced transcriptomics. Sci Rep. 2017;7(1):1-5.

56. Rahman M, Browne JJ, Van Crugten J, Hasan M, Liu L, Barkla BJ. In silico, molecular docking and in vitro antimicrobial activity of the major rapeseed seed storage proteins. Front Pharmacol. 2020;8(11):1340.

57. Hossain MK, Khatun A, Rahman M, Akter MN, Chowdhury SA, Alam SM. Characterization of the effect of drug-drug interaction on protein binding in concurrent administration of sulfamethoxazol and diclofenac sodium using bovine serum albumin. Adv Pharm Bull. 2016;6(4):589.

58. Krishnamoorthy S, Honn KV. Inflammation and disease progression. Cancer Metastasis Rev. 2006;25:481-91.

59. Balkwill F, Mantovani A. Inflammation and cancer: back to Virchow? Lancet. 2001;357:539-45.

60. Khatun $A$. The impact of rice protein and lipid on in vitro rice starch digestibility. In: Southern Cross plant science. Lismore: Southern Cross University; 2019.

61. Rahman M. Identification, molecular and proteomic characterisation of Brassica rapa seed storage proteins with allergenic and antimicrobial potential. In: Southern Cross plant science. Lismore: Southern Cross University; 2020.

62. Zihad SMNK, Bhowmick N, Uddin SJ, Sifat N, Rahman MS, Rouf R, et al. Analgesic activity, chemical profiling and computational study on Chrysopogon aciculatus. Front Pharmacol. 2018;9:1164.

63. Islam MK, Acharzo AK, Saha S, Hossain H, Shilpi JA, Das AK, et al. Bioactivity studies on Zanthoxylum budrunga Wall (Rutaceae) root bark. Clin Phytosci. 2018;4:24.

\section{Publisher's Note}

Springer Nature remains neutral with regard to jurisdictional claims in published maps and institutional affiliations.

\section{Submit your manuscript to a SpringerOpen ${ }^{\circ}$ journal and benefit from:}

- Convenient online submission

- Rigorous peer review

- Open access: articles freely available online

- High visibility within the field

- Retaining the copyright to your article 